\title{
Karstenella vernalis Harmaja, a new genus and species of Discomycetes from Finland
}

\author{
HarriHarmaja \\ Department of Botany, University of Helsinki, Helsinki, Finland.
}

Karstenella Harmaja, n. gen.

Genus Discomycetum, verisimiliter ex ordine Pezizales. Ascocarpus tenuissimus, omnino stricte ad substratum appressus (haud apothecium sensu stricto), probabiliter gymnocarpus. Sporae unicellulatae, satis tenuitunicatae, in $\mathrm{KOH}$ hyalinae, in solutione Melzeri subflavidae, in "Cotton Blue in acido lactico cyanophiloidae. Asci eutunicati, unitunicati, operculati, satis tenuitunicati, tunica ad apicem ejusdem crassitudinis, cylindracei, octospori, in solutione Melzeri haud caerulescentes, sporas per ascostoma leniter obliquum ejectant. Paraphyses recti, simplices, filiformes, in solutione Melzeri haud colorescentes. Excipulum omnino e textura intricata. Subiculum (?) e hyphis tenuibus intricatis, hypharum excipuli dissimilibus.

Typus gen eris: Karstenella vernalis Harmaja.

Karstenella vernalis Harmaja, n. sp.

Ascocarpus tenuissimus, omnino stricte ad substratum appressus, surrotundus, 3-12 $\mathrm{mm}$ in diam., pro maxima parte fuscoruber, ad marginem pallidior, aurantiacus-chlorinus. Probabiliter gymnocarpus. Sporae 12,0-15,0 $\times$ 5,5-7,2 $\mu \mathrm{m}$, uniseriatae, ellipsoideae, equilaterales, satis tenuitunicatae (tunica ca. $0,4 \mu \mathrm{m})$, laeves, perispora non observatur, in KOH hyalinae, in solutione Melzeri subflavidae, in «Cotton Blue in acido lactico cyanophiloidae, sporae intus eguttulatae, homo- geneae. Asci $150-190 \times 8,0-12,5 \quad \mu \mathrm{m}$ (longitudo tota), cylindracei, octospori, apice leniter attenuato et curvato quando maturi, in $\mathrm{KOH} \pm$ hyalini, in solutione Melzeri flavidi, tunica omnino satis tenui (ca. 0,5 $\mu \mathrm{m}$ ), ascostomate leniter obliquo. Paraphyses valde tenuitunicati, recti, simplices, filiformes, apice saepe leniter incrassati $(3,0-6,0 \mu \mathrm{m})$, haud incrustati, parce septati, plasmate in $\mathrm{KOH}$ sordide pallide viridi, in solutione $\mathrm{Mel}$ zeri sordide flavido. Excipulum e hyphis filiformibus, 3,0-5,0 um crassis, septatis, defibulatis, tenuitunicatis, laevibus, in $\mathrm{KOH}$ hyalinis-subflavidis, in solutione Melzeri subflavidis. Pars exterior excipuli e textura intricata typica; in parte interiore hyphae minus intricatae, multae earum horizontales. Subiculum (?) e hyphis filiformibus intricatis subter ascocarpo in substrato sitis constat, quae simul marginem angustum albidum ascocarpi formant. Hyphae subiculi 3,5-7,5 $\mu$ m crassae, rectangulare ramosae, septatae, defibulatae, satis crassitunicatae, dense papillatae, in $\mathrm{KOH}$ flavidae-brunneolae, in solutione Melzeri pallide fuscae, valde cyanophiloidae in «Cotton Blue in acido lactico.

Ad terram et ad ramulos putrescentes Coryli avellanae et in detrito alio, plerumque Coryli. Vernalis.

Holotypus in museo botanico universitatis Helsinkiensis $(H)$ conservatus, legit Harri Toppari 30.5.1967 in Fennia australi, prov. Varsinais-Suomi, in silva decidua in Virkkala, Pähkinäniemi paroeciae Lohja. 
Karstenella ${ }^{1}$ Harmaja, n. gen.

Ascocarp very thin, totally tightly appressed at the substrate (not being a true apothecium), its development probably gymnocarpic. Spores one-celled, rather thin-walled, hyaline in $\mathrm{KOH}$, slightly yellowish in Melzer's, blue in Cotton Blue (Methyl Blue) in lactic acid. Asci with persistent wall of the unitunicate type, discharging their spores with a puff, operculate, rather thin-walled, apex not differentiated, cylindrical, eight-spored, not blueing with Melzer's. Excipulum throughout composed of more or less interwoven, filamentous hyphae (textura intricata). Subiculum (?) composed of interwoven, filamentous hyphae of other kind than those of the excipulum.

Type species: Karstenella vernalis Harmaja.

Karstenella vernalis Harmaja, n. sp.

Ascocarp very thin, in the middle ca. $0,4-0,7 \mathrm{~mm}$, getting thinner towards the edge where it is membranaceous and translucent especially in young specimens, totally tightly appressed at the substrate, uneven because adapting the features of the substrate, roundish, 3-12 $\mathrm{mm}$ in diam., in fresh as well as dried condition mostly brownish red, paler towards the edge (orange-coloured), extreme margin greenish yellow especially in young specimens. The ascocarp is bordered with a whitish, ca. $1 \mathrm{~mm}$ broad mycelial zone (= subiculum?). Development of the ascocarp probably gymnocarpic. Spores $12,0-$ $15,0 \times 5,5-7,2 \mu \mathrm{m}$, uniseriate, ellipsoid, thickest in the middle, equilateral, rather thin-walled (wall ca. 0,4 $\mu \mathrm{m}$ thick), com-

1 In the honour of P. A. Karsten, the great Finnish student of Discomycetes. pletely smooth, no perispore observed, hyaline in $\mathrm{KOH}$, slightly yellowish in Melzer's, blue in Cotton Blue in lactic acid, the contents of the spores are homogeneous without guttules. Asci 150-190 × 8,0-12,5 um (total length), cylindrical, eight-spored, apex slightly tapering and curved when mature, \pm hyaline in $\mathrm{KOH}$, yellowish in Melzer's, their wall everywhere rather thin (ca. 0,5 $\mu \mathrm{m})$, ascostome slightly oblique. Paraphyses very thin-walled, straight, unbranched, sparsely septate, almost equal or slightly enlarged above where $3,0-6,0 \mu \mathrm{m}$ broad, not encrusted, contain homogeneous plasma dirty greenish in $\mathrm{KOH}$, dirty yellowish in Melzer's. Excipulum throughout composed of filamentous hyphae, which are $3,0-5,0 \mu \mathrm{m}$ broad, septate, clampless, thin-walled, smooth, hyaline to slightly yellowish in $\mathrm{KOH}$, slightly yellowish in Melzer's. The outer part of the excipulum (about half of it) is typical textura intricata; in the inner part many hyphae tend to run horizontally and the aspect of the layer is slightly less intricate than that of the outer part. The excipulum ties the ascocarp tightly onto the substrate. The margin of the ascocarp is at least in young specimens sterile, composed of textura intricata just like the outer excipulum. Immediately below the ascocarp there occur interwoven, filamentous hyphae in the substrate and these hyphae form the whitish, narrow border of the ascocarp. These hyphae must probably be interpreted as a subiculum and they are 3,5-7,5 um broad, septate, without clamps, rather thick-walled, in $\mathrm{KOH}$ yellowish-brownish, in Melzer's somewhat darker, pale brown, deep blue in Cotton Blue in lactic acid. The hyphae are branching; the branches are always rectangular. Especially in ladder-like connec-

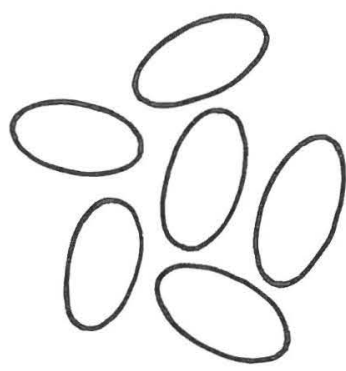

a

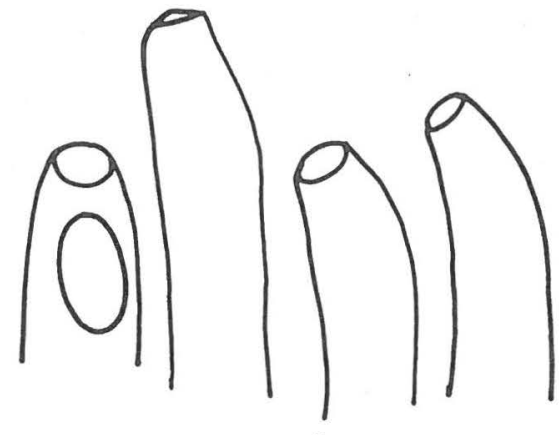

b

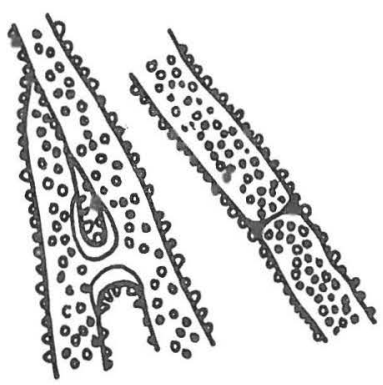

C

Fig. 1. Karstenclla vernalis Harmaja. a) spores in heated Cotton Blue, b) tips of asci, c) subicular hyphae. All x 1000 . Drawn from the holotype. 
tions between hyphae the rung ( $\mathrm{H}$-piece) has thickened walls (fig. 1, c). The walls of the subicular hyphae are densely papillate excluding some branches where the papillae first diminish gradually and then end leaving the other end of the hypha smooth. The papillae are strongly cyanophilous as is the hyphal wall and they are up to $1 \mu \mathrm{m}$ high and about 0,5 $\mu \mathrm{m}$ broad throughout, and truncate.

On mould and decaying twigs of Corylus avellana as well as in other kind of litter, mostly of Corylus. Vernal.

Holotype preserved at Helsinki $(\mathrm{H})$, collected by the author (whose former surname was Toppari), 30.5.1967 in southern Finland, prov. Varsinais-Suomi, parish Lohja, in deciduous forest in Virkkala, Pähkinäniemi.

This peculiar fungus is known only from the type locality in southernmost Finland where it grew in deciduous rich forest with predominant Corylus and the herb Aegopodium podagraria. When the fresh fruit-bodies were touched the spores were seen to be discharged as a cloud and a hissing sound like that usually produced by Discomycetes was heard.

Though being discomycetous the species, however, has not a typical apothecium as its ascocarp. The fruit-bodies are merely thin coverings on forest litter, adapting the unevennesses of the substrate, even the venation of decaying leaves of Corylus! Among characters peculiar to Karstenella is the colouring of its ascocarp. The differences in colours between the middle part and the margin are probably due to the flesh being thinner towards the margin and thus different absorption and reflection of light. It is to be emphasized that inflated cells occur neither in the excipulum nor in the margin but the latter are throughout composed of more or less interwoven, filamentous hyphae (textura intricata). Very curious are the hyphae which occur below the fruit-body and border it (see description), obviously constituting one kind of subiculum.

Karstenella has such characters that it does not fit with any genus described in Pezizales or Helotiales. In fact, I even dare not place it into any of their families. Though I have not seen an opened persisting lid I am convinced that the asci are operculate. In almost mature asci there is a dehiscent line at the apex and when mature they have a regular, slightly oblique round ascostome. The asci are not conspicuously protruding when mature. In the revised system of Pezizales by Eakblad (1968) Karstenella would have an isolated position. In Helotiales there are two genera without apothecium and even without a true ascocarp (Ascocorticium Earle and Ascosorus P. Henn. \& Ruhl. ap. P. Henn.; for their descriptions, see Oberwinkler, Casagrande \& Müller 1968 resp. v. Arx 1963), but in no case has my genus anything to do with them.

\section{LITERATURE}

Arx, J. A. von, 1963: Die Gattungen der Myriangiales. - Persoonia 2, 421-475.

ECKBLAD, F.-E., 1968: The Genera of the Operculate Discomycetes. A re-evaluation of their Taxonomy, Phylogeny and Nomenclature. - Nytt Mag. Bot. 15, 1-191.
Oberwinkler, F., F. Casagrande \& E. Müllet, 1968: Úber Ascocorticium anomalum (Ell. et Hark.) Earle. - Nova Hedwigia 14, $283-289$. 